\title{
Lake Drawdown Revisited: The Value Of Two Inches Of Water
}

Russell Kashian, University of Wisconsin - Whitewater, USA

Alexander Walker, University of Wisconsin - Whitewater, USA

Matthew Winden, University of Wisconsin - Whitewater, USA

\begin{abstract}
This paper uses a hedonic price model to estimate the impact of water level on the value of real estate on Lake Koshkonong in Wisconsin. Hedonic techniques are employed to show that a reduction in the lake's water level has a significant effect on shoreline property values. The body of existing research demonstrates that changes in both the subjective and objective indicators of value are important for estimating the implicit value of water quality in hedonic analysis. This paper provides new evidence on the economic harm to lake communities created by the reduction of water levels.
\end{abstract}

Keywords: Water Value; Property Value; Hedonic Analysis; Water Quantity

\section{Highlights}

1. The contribution of the shoreline reduction to any change in the value of properties

2. Depreciation of Lake Koshkonong properties compared to other lakes

3. Average change in property values for each lake

4. Total lost sales tax revenue for Lake Koshkonong

\section{INTRODUCTION}

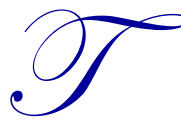

his paper addresses the property value impact created by a 1991 Wisconsin Department of Natural Resources (DNR) order to lower the water level in Lake Koshkonong. This lake, located between Madison, Milwaukee, and Chicago is a shallow lake at only seven feet deep, but encompasses 10,000 acres of area. In addition, Koshkonong has over 400 homes with lakefront property. As the prior literature on water level economics has found, a reduction in the potential high water mark of a lake can result in a lower level of relative property value appreciation for housing stock with water frontage.

Although Koshkonong is a natural lake, its size and level were impacted by the creation of the Indianford Dam. In recent years, the water level has been a source of contention due to a 1991 DNR order requiring Lake Koshkonong to lower its water level below its historical norm. The order effectively resulted in lake levels falling approximately 0.5 feet below normal for half of the summer season, rising above normal for $10 \%$ of the summer season and remaining at the historical norm of the last 18 years for the remaining $40 \%$ of the summer season. This order resulted in uncertainty to both actual and potential homeowners regarding the shoreline and lake water level, ultimately decreasing property value appreciation in comparison to other similar regional lakes.

The economic challenges created by the 1991 DNR order include: (a) Potential loss of pier functionality and the ability to use piers for boating, swimming and other water activities for all or portions of the period between May and October (the summer season); (b) Loss or diminishment of the ability to access the shoreline by watercraft; (c) Degradation of the appearance of the shoreline and exposure of "mud flats" under low water level conditions; (d) Reduction of areas of navigability by larger motorized craft; (e) Exposure of rocks and other obstacles that can damage watercraft. This paper contributes to the literature on the value of water through an updated and expanded examination of Lake Koshkonong using hedonic techniques to quantify the economic effects of lower water levels on housing appreciation. 


\section{LITERATURE REVIEW}

\section{The Value of a Lake Lot to the Homeowner}

Hedonic techniques estimate the implicit prices of attributes which characterize a product through examination of observed prices of the product across different levels and combinations of the attributes. Econometrically, implicit prices are estimated through a first-step regression analysis (Rosen 1974). In the context of this study, the product of interest is housing. In terms of housing, hedonic values are the result of a model of equilibrium housing price differentials. This model hypothesizes that homeowners maximize their utility by trading-off between differences in home prices and the associated attributes which make up different housing units.

A given housing unit is best characterized as a bundle of attributes which describe the structure itself (e.g. bedrooms, bathrooms), the land upon which it is built (e.g. acres, proximity to lake), and relevant locational characteristics (e.g. schools, crime). Claims of valuation comparisons which ignore the differences between these units ignore the uniqueness of each bundle of attributes. Thus, proximity to water, water depth, and length of shoreline are three of the housing bundle's locational attributes. There exists a given distribution over space of the supplies of these attributes, since the housing stock alters only slowly over time and the attributes are inelastic in supply (Brown and Pollakowski 1977), albeit natural disasters or governmental actions can alter that supply.

When forming policy, hedonic analysis provides decision makers with the ability to explore the supply and demand aspects of environmental goods. While the physical environment helps shape supply issues, obtaining the demand curve requires knowledge of the prices that consumers are willing-to-pay. With marketed goods, such prices are observable, but it is often difficult to isolate the value of environmental amenities because they are bundled into the price of the entire property along with all of the other hedonic attributes. In this study, examining the value of a certain amount of shoreline footage constitutes just such an environmental amenity. Since it is almost impossible to purchase a single foot of shoreline (not associated with lot acreage), hedonic analysis extracts the contribution of the environmental good, which is an attribute embedded in the hedonic characteristics comprising a housing unit, to the overall price of the housing unit.

While economists generally assume that people know their preferences with certainty and their purchasing choices are based on observable, well-understood measures of the goods and services they consume (as well as the component characteristics which comprise those goods and services), this may not be the case when considering complex, heterogeneous commodities where some component characteristics are not observed. For instance, in the case of housing markets, characteristics such as the number of bedrooms are easily observed and quantified. On the other hand, some characteristics, such as the property's environmental quality, may not be readily observable. These characteristics, however, may be inferred by the purchaser with background research on a property. In the case of this study, changes in lake levels over time can be found and appear to impact purchasing decisions of home buyers.

\section{Water Quality}

Economic psychologists recognize that objective data may not represent valid measures when used as proxies for analyzing consumer decision making behavior (Singh 1988). Puto (1987) suggests that consumer decisions over public goods that are purchased as part of a heterogeneous marketed good tend to be based on their expectations or internal assessment of the public good. Likewise, Payne (1982) suggests that buying decisions are dependent upon perceptual factors. As such, consumers' subjective assessments are included in Payne's modeling framework. Factors such as these are important to consider in the case of environmental amenities associated with housing units, as the quality of the associated amenity may be difficult to objectively characterize in the description of the home and therefore lead to subjective interpretations by potential purchasers.

David (1968) used the hedonic technique when observing how water quality affects lakeshore properties on artificial lakes in Wisconsin. She found that property prices were significantly correlated with a measure of water quality that represented levels of lake pollution, with water quality measurements provided by an expert. This early work was instrumental in the creation of subjective measurements of the economic value of an environmental amenity. 
Epp and Al-Ani (1979) estimated two different equations based on lake water quality and its impact on lake property values. Both were quantitative analyses, using Secchi depth measurements, as well as qualitative analysis from individual perceptions, which yielded significant and positive relationships between water quality and property value. Young and Teti (1984) studied the effect of perceived water quality in the vicinity of St. Albans Bay on Lake Champlain in Vermont. The inclusion of water quality perceptions resulted in a significant and negative relationship between perceived degraded water quality and lake home sale prices.

Colwell and Dehring (1995) used hedonic analysis to compare the frontage and depth pricing of lake properties, controlling for price differentials across three different towns included in the analysis. They found that whether or not a lot is directly located on a lake is critical to the price of the house and that quality of the lake also affected the price of the house.

Michael, Boyle, and Bouchard (2000) rated lakes for both subjective and objective water clarity. The results revealed that implicit price estimates proved significant; both the objective and subjective variables produced significant coefficients. The authors concluded that the significance of the subjective variable creates a concern that these coefficients are dependent on policy recommendations that may ignore the public perception of environmental quality. As a result, public perception and public policy may be in conflict.

Poor et al. (2001) used an objective measure of an environmental amenity, water clarity for lake front property owners, in a hedonic model and compared it to the use of a directly comparable subjective measure of the same amenity. The coefficients on both water clarity variables were significant. However, while the subjective measure was positive and significant (the greater the perceived water clarity, the higher the price), it was not as accurate in predicting sales prices as the objective variable.

Krysel et al. (2003) used hedonic pricing to examine lakeshore property on thirty-seven different lakes in Minnesota that were then separated into six market groups. Once the data was collected for all the lakes, Krysel et al. analyzed it using a regression which related property price to housing characteristics, as well as water quality. Their study found that the water quality variable significantly affected prices paid for lakeshore property, showing that individuals pay more for houses that have those amenities.

\section{Distance from Waterfront and Shoreline Length}

In addition to water quality measures, a variety of location issues impact the value of real estate. Parsons and $\mathrm{Wu}$ (1991), using 2002 dollars, found that the value of a home falls by $\$ 4,175$ for every mile it is farther away from water. In this study, the mean sales price was $\$ 181,341$. Michael, Sides and Sullivan (2003) found that for each 100 meters of distance from shore, Maryland property values decreased by about 3-4\% in Shady Side and Piney Point, and by $18 \%$ on the Hooper Islands located in the State of Maryland. In the case of unimproved real estate, the decrease was lower, at between $2 \%$ and $4 \%$.

Besides distance to water, another economic concern regarding the lowering of a lake's water level is its impact on quantity of shoreline. The reduction of water inside the lake ultimately results in less area covered by the lake, and thus a reduced total length of shoreline. Given there is an implicit value in a foot of shoreline, the elimination of shoreline eliminates wealth. This claim is well-documented. Boyle and Taylor (2001) used hedonic models to estimate implicit prices on freshwater lakes and ponds in Maine, including the sales of properties with frontage on 34 lakes between 1990 and 1995. The lakes were segmented into four market groups whose shoreline was worth between $\$ 72$ and $\$ 456$ a foot. Krysel et al. (2003) considered residential sales from 1996 to 2001 on thirty seven lakes of various size and geography. Assigning the 1205 residential sales to one of six lake groups created realistic market areas. This study found that the value of a foot of lake frontage ranged from $\$ 80$ per foot to $\$ 421$ per foot.

Conner, Gibbs and Reynolds (1973) looked at the value of lake or canal land frontage. A sample of vacant residential lots in Florida produced a value of $\$ 40$ per frontage foot. Poor et al. (2001) found that an additional ten feet of shoreline increased property values by between $\$ 83$ and $\$ 170$ on lakes and ponds located in Maine. 


\section{Reduction in Water Level}

In a pattern similar to the earlier research, the following studies provide insight into the general direction housing values take as the result of a drawdown. Because a lake's water level is implicitly an attribute associated with lakefront property, any changes to the water level have the potential to impact the value of housing. The results are each consistent with the hypothesis that the drawing down of a lake's level results in reduced property values for real estate on the lake.

Early work by Khatari-Chhetri and Hite (1989) looked at the impact of drawdowns on the sales price of vacant lots in South Carolina. They estimated that each vertical foot of drawdown reduces sale price by $\$ 8,454$ per acre.

More recently, Lansford and Jones (1995a, 1995b) estimated shoreline value around two Texas lakes, finding that water level at time of sale is worth about $\$ 914$ per foot of elevation. The average impact of a six foot drawdown is approximately $\$ 9,492$. Their study found three statistically significant hedonic characteristics that affect sale prices: distance from lake, scenic view, and water front location. After analyzing these characteristics, they discovered that distance to a lake was the most important for recreational and aesthetic value. Additionally, the study determined that the farther a house is from a lake, the lower the implied value of recreation and aesthetic value. They also found that lakefront property impacts the value of all homes in a town containing a lake, increasing values by 20 percent.

In an exhaustive study on the "Economic Effects of TVA Lake Management Policy in East Tennessee", Murray (2003) looked at the economic impact of a winter drawdown. The winter drawdown results in a decrease in the value of lake properties of between $1 \%$ and $5 \%$. In addition, the benefits of delaying the winter drawdown until September 1st range from $\$ 35$ to $\$ 4,950$ per parcel on Douglas Lake. Furthermore, the more valuable the property associated with the lot, the larger the effect. Finally Hanson and Hatch (2001), drawing on a contingent valuation model, determined that a permanent one foot reduction in the summer water level results in a $4 \%$ to $15 \%$ decrease in property value.

\section{Quality of Lakeshore Properties}

Scenic beauty, peace, quiet, and being removed from urban living give some people higher utility than from living in the suburbs or the city, making lake properties appealing to such people. "The water quality standards of the Clean Water Act (1977) and related state standards require lakes to support uses for fishing, swimming, aquatic life support, and human fish consumption" (Michael et al. 1996). These improvements make the lake more useful, which in turn causes an increase in the demand for lakefront property. Residents living on lakes value these features to such an extent that their presence can often be a positive externality, improving water quality and conservation. "The benefits from tourism, water supply, lakeside property, and environmental quality also play important factors in the value of reservoir management" (Yates 2009). The government has spent thousands of dollars on the Clean Water Act (1977) to keep water clean. "Over the last decade, $\$ 80,000$ to $\$ 250,000$ a year has been allocated by the state for lake protection and restoration" (Michael et al. 1996). Local government also spends money to keep the lake looking nice to enhance tourism. The beauty of a lake is one of the biggest factors influencing lakefront property values. "Lake-front property owners are potentially the recipients of the greatest economic gains from improved lake-water quality because the benefits of water quality can be capitalized in the price of lake-front properties" when they are sold (Michael et al. 1996).

\section{Lakefront Properties on a Local Tax Base}

The gains in property value do not solely accrue to the homeowners though. Lake front properties have a large impact on counties' tax bases. Williams (1994) looked at waterfront properties in Lake Blackshear and documented the positive impact it had on the tax base for that county. He found that lakefront properties accounted for 12.4 percent of residential parcels, but those properties contributed 27.9 percent of the counties total residential tax base, or $\$ 646,680$ in taxes.

Since Lakefront properties can raise tax revenues, Gibbs et al. (2002) decided to analyze the impact of water clarity declines on the tax base. Their results showed that a decline in lake water clarity causes a decrease in local property 
tax revenues. A large number of lakefront properties lost value and, because of this loss in value, the government experienced declines in tax revenue.

\section{MODEL}

In order to examine the impact of the 1991 lake drawdown order issued by the Wisconsin DNR, a hedonic analysis examining the order's impact on lakefront property values across several similar Wisconsin lakes was undertaken. Data for the study were drawn from the County Assessor and Treasury Database, which provides information regarding single family home sales from 1997 to 2013 at Lake Koshkonong and three comparable large shallow lakes in Wisconsin. In addition to housing sales for lake front property on Lake Koshkonong, the data collected also include homes sold on three other lakes of similar size and depth as Lake Koshkonong from 1997 to 2013, including Lake Sinissippi, Lake Beaver Dam, and Lake Big Muskego. It should be noted that the nominal property values on Lake Beaver Dam did not appreciate over this time frame.

The formal model recognizes the internal and locational attributes of lakefront real estate. Internal attributes include such characteristics as bathrooms, bedrooms, square feet of house, amount of lake frontage, lot size etc. Being on a lake gives the properties unique characteristics that other houses would not have, one of which is distance from the lake in feet. The distance in feet is recorded in our table as Near_Distance_Ft. If any one of these characteristics were to change it could affect the demand for the property. Sometimes characteristics are more in demand than others, so having multiple characteristics could mask some of these effects. For example, if the demand for more lake frontage on Lake Koshkonong were to decrease but all other characteristics of the house were to improve, the total increase in demand from all the other characteristics could outweigh the single attribute. This does not mean that lake frontage is insignificant in determining the demand of the house as a whole; it simply indicates that if people demanded lake frontage on Lake Koshkonong slightly more than for houses on Lake Koshkonong, there would have been a larger increase in value.

The purpose of this study is to determine if a particular environmental amenity can change the demand for a house. In this case, the environmental amenity is the amount of lake frontage. By isolating the demand for lake frontage at housing units along Lake Koshkonong from the other characteristics (such as housing specific attributes), we can determine whether changes in Lake Koshkonong's water level have altered the demand for houses and, if so, by how much.

The data available consists of information on houses sold between 1997 and 2013 at Lake Koshkonong and the three other lakes, which serve as controls. There were 308 houses that were sold on all four lakes in this 16 year span. There were 39 houses sold on Lake Big Muskego, 47 on Lake Koshkonong, 91 on Lake Sinissippi, and 131 on Lake Beaver Dam. The frontage of the lakes was calculated from GIS maps from the Dane, Dodge, Jefferson, Rock, and Waukesha county websites.

Lake Beaver Dam, Lake Sinissippi, and Lake Big Muskego were each chosen because of their similar size and depth to Lake Koshkonong. Lake Beaver Dam covers 6,542 acres and has a maximum depth of seven feet, Sinissippi covers 2,800 acres and has a maximum depth of eight feet, and Big Muskego covers 2,260 acres and has a maximum depth of eight feet. Similarly, Lake Koshkonong covers 10,460 acres and has a maximum depth of seven feet. The physical features of each of these lakes make them similar in terms of recreational activities. Beaver Dam and Sinissippi are both located in Dodge County, Koshkonong is located in Jefferson, Dane, and Rock County and Big Muskego is located in Waukesha County. All four lakes are located in relatively similar geographic areas. However, it should be noted that Beaver Dam Lake is the most remote, although it is within the metropolitan real estate market. Its ultimate lack of relative appreciation is not surprising due to this market constraint. However, all four lakes are within driving distance of Madison, Milwaukee, and Chicago. Lake Koshkonong is the second closest lake to Chicago out of the four lakes, next to Lake Big Muskego. Its close proximity should raise prices relative to Lake Beaver Dam and Lake Sinissippi, but this study hypothesizes that the lowering of water levels will give Lake Sinissippi, Lake Beaver Dam, and Lake Big Muskego higher appreciation values, with Lake Big Muskego having the highest appreciation out of the four because of its close proximity to large metropolitan populations in Chicago and Milwaukee. Relevant lake characteristics are reported in Table 1. 
A hedonic pricing equation is used to determine the appreciation of lake frontage real estate on the four lakes over the past 16 years. The hedonic equation tests the relationship between the independent variables (lake frontage, lake, bedrooms, bathrooms, total rooms, and square feet of the house) and the dependent variable (sales price) to determine whether or not lower lake levels affected property values. With the hedonic regression, a number of explanatory variables are included which may influence residential property prices. To control for unobserved lake characteristics for any given time period, interaction dummies were created that indicated the lake, time epoch, and lake frontage for each observation. The three time epochs include: pre-dam repair (1997-2002) where lake levels were at their historical norms, post-dam repair (2003-2007) where lake levels changed relative to their historical norms, and post-dam repair during and after the "great recession" (2008-2013) to control for the impact of both the changed water levels relative to historic norms and economic conditions present during this period. Home sales across the 3 epochs are relatively balanced with around $1 / 3$ of total observations occurring during each epoch. During the first epoch (1997-2002), 73 homes were sold across the four lakes. 106 homes and 129 homes were sold in epochs 2 (2003-2007) and 3 (2008-2013) respectively.

The literature cited earlier is replete with studies that have used these types of housing characteristics. The variables used in this study are similar to those used by Brown and Pollakowski (1977) and Palmquist (1984). In their analyses, they included variables such as number of bedrooms, number of bathrooms, square feet of living space, central air conditioning, the existence of an attached garage, the existence of a basement and other controls. Boyle and Taylor (2001) use shoreline feet to estimate value. The specific hedonic models estimated in this manuscript are outlined in the following section. Table 2 provides the descriptive statistics.

The functional form of the hedonic model is:

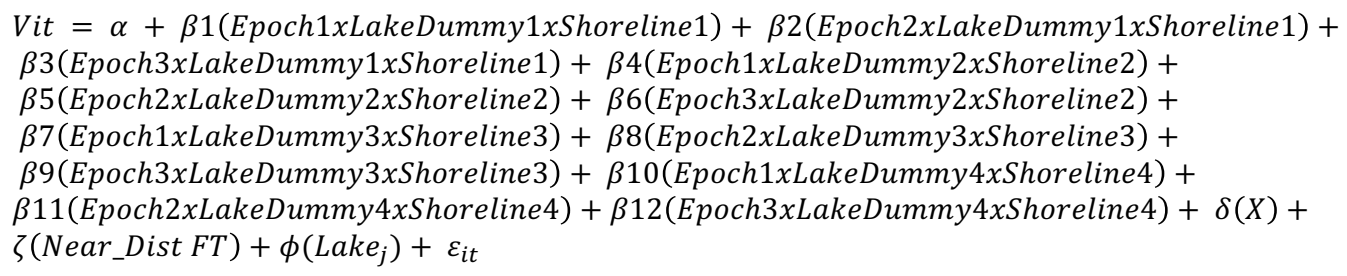

Epoch $x$ LakeDummy $y_{j}$ Shoreline is a series of interaction terms between the frontage of the property (shoreline), the epoch time indicator variables (indexed by 'i') and either Lake Koshkonong, Lake Sinissippi, Lake Big Muskego or Lake Beaver Dam (indexed by ' $\mathrm{j}$ '); $X$ is a vector that includes the logged ratio of lot size in square feet to the lineal feet of lake frontage, house square feet, number of rooms in total, number of half-bathrooms, and number of bathrooms as housing characteristic variables; $L_{a k e}$ represents the lake variable multiplied by the year sold indicator; the distance in feet each house is from the water, both squared and unsquared, is represented as Near_Dist_FtSqrd and Near_Dist_Ft respectively. 


\section{RESULTS}

The results of the hedonic regression can be seen in Table 3. The significance and sign on the coefficients for halfbaths, bathrooms, and total rooms are consistent with expectations as well as values found in the earlier literature. Square Feet of House and Ln (Lot Size/Frontage) have the expected signs but are not statistically significant. This is likely due to high correlation between the other house hedonics (i.e. total rooms) for the square footage regressor and high correlation between the frontage-epoch interactions for the logged frontage regressor. These variables were still included because the theoretical underpinnings of the model indicate they are a necessary component of a hedonic price regression for housing.

Estimating appreciation over time for a foot of lake frontage on Lake Koshkonong relative to Lake Beaver Dam, Lake Sinissippi, and Lake Big Muskego is the main objective of the model. In other words, we attempt to determine the contribution of the shoreline to any change in the value of properties, ceteris paribus. Since the LM heteroscedasticity test indicates heteroskedastic variance of the error term, we apply a procedure proposed by White (1980) to generate heteroscedasticity-consistent estimates.

For the reasons set forth in the literature review, and assuming that the dam repairs resulted in a corresponding decline in water levels at Lake Koshkonong, the results of this model are expected to indicate there was a slowdown in the appreciation of a foot of shoreline at Lake Koshkonong relative to the other lakes. Lake Koshkonong's change in value per foot of shoreline is expected to have increased, but more slowly than the other lakes from Epoch 1 to Epoch 3 owing to the reduction in water level. As seen in Table 3, the results of the hedonic model support the hypothesis.

To calculate the change in value per lineal foot, the coefficient estimate on Epoch ${ }_{3} x$ LakeDummy $x$ Shoreline is subtracted from the value of the coefficient estimate on Epoch ${ }_{1} x$ LakeDummy $_{i} x$ Shoreline. This is the average change in housing value attributable to lake frontage over the time period studied. This value is multiplied by the number of homes on lake ' $\mathrm{j}$ ' (to calculate the total change in value for the lake attributable to frontage) and then divided by the total number of lineal feet of frontage for lake ' $j$ '. The values used for number of homes and lineal feet of frontage for each lake can be found in Table 1. The average increase per foot of shoreline is calculated at $\$ 9.03, \$ 8.24$ and $\$ 38.78$ for Koshkonong, Sinissippi and Big Muskego respectively (Beaver Dam's value per lineal foot is unchanged). The change in the value per lineal foot between Sinissippi and Koshkonong is very close in value. But, the relative change in appreciation attributable to frontage on these two lakes relative to Big Muskego is quite large. The difference in value between Koshkonong and Big Muskego is $-\$ 29.75$ per lineal foot of frontage and for Sinissippi is $-\$ 30.54$. The relative slowdown in appreciation of the value of a foot of shoreline at Lake Koshkonong, as compared to Lake Big Muskego, is supported.

We next sought to identify the average change in value for each lake. To begin, we calculate the total change in property value, attributable to both the value of frontage (as calculated above) and the value of being a lake lot. Changes in the value of a property associated with lake frontage are not only tied to the amount of frontage, but the fact the home is located on a lake lot. To calculate the total change in property value from epoch 1 to epoch 3 , the coefficient estimate on Epoch ${ }_{3} x$ LakeDummy $x$ Shoreline from Table 3 is multiplied by the total lake frontage in feet on lake ' $\mathrm{j}$ ' found in Table 1. This amount is summed with the coefficient on Epoch ${ }_{3} x$ Lake $_{j}$ multiplied by the number of homes found on lake ' $\mathrm{j}$ '. This same calculation is repeated for epoch 1 values across all lakes. The epoch-lake coefficients denote the average change in a home's overall lake lot value (independent from the frontage). The sum of these two calculations gives the total value change for each lack in each epoch. To calculate the total change in value across epochs, the values calculated for epoch 3 for lake ' $j$ ' are subtracted from the values calculated in epoch 1 for lake ' $\mathrm{j}$ '. The result is divided by the total number of lake front homes on lake ' $\mathrm{j}$ ' to derive the estimated average change in value for a lake front home on lake ' $\mathrm{j}$ '.

On average, home values on Lake Koshkonong increased by $\$ 54,000.12$ over the time period studied; Lake Sinissippi home values increased by an average of $\$ 74,226.41$ and Lake Big Muskego home values saw an average increase of $\$ 149,177.83$. The statistically significant difference in value between Lake Koshkonong and the other lakes suggests that the change is peculiar to Lake Koshkonong as opposed to a change that altered lake frontage generally. Since the total value increase for Lake Koshkonong is so much lower than for the other lakes, there is 
reason to believe that this change in demand for lake frontage on Lake Koshkonong is because of Indianford Dam and the lowering of the water levels.

Having estimated the average change in value per home on the different lakes, we can know derive the total lost tax revenue for Lake Koshkonong. To identify total lost tax revenue for Lake Koshkonong, we subtracted Lake Sinissippi's average increase in value $(\$ 74,226.41)$ from that for Lake Koshkonong $(\$ 54,000.12)$, and multiplied the result $(\$ 20,226.29)$ by the total number of houses on Lake Koshkonong (413). This provides an estimate of the total lost property value for Koshkonong if home appreciation had matched that seen for homes on Lake Sinissippi. The result was then divided by 1000 and multiplied by the mil rate for Koshkonong ( $\$ 14$ per $\$ 1000$ of home value) to yield an estimate on the lost or "missing" tax revenue experienced by Koshkonong from the water level drawdown relative to what it might have otherwise been. The same exercise was repeated for Lake Big Muskego. We estimate that Lake Koshkonong lost $\$ 116,984.40$ in yearly tax revenues compared to Lake Sinissippi and $\$ 550,317.54$ in yearly tax revenues compared to Lake Muskego because of the water level reduction in Lake Koshkonong (see Table 4).

To provide context to the size of these missing tax revenues, the Towns of Koshkonong and Sumner (containing the predominant number of all Lake Koshkonong homes) had property tax collections of \$6,214,871 and \$2,060,260 in 2014 respectively. Total property tax collections were therefore $\$ 8,275,131$. The difference in tax revenue collected based on Sinissippi appreciation $(\$ 116,948)$ represents $1.4 \%$ of property tax revenue for Koshkonong and Sumner in 2014. The difference in tax revenue collected based on the higher appreciation seen on Big Muskego $(\$ 550,317.54)$ represents $6.7 \%$ of property tax revenue for Koshkonong and Sumner combined. In both cases, this represents a substantial loss in revenue for the towns.

\section{CONCLUSION}

This study explores how the Wisconsin DNR's decision to lower the level of Lake Koshkonong impacted lake front property values, using a hedonic regression. The analysis showed that the decision resulted in financial harm to the homeowners and to the community around the lake. The link between property value appreciation and the change in water level was quantified and found to be statistically significant.

This analysis showed that if Lake Koshkonong's water level had not been reduced, it would have enjoyed a higher appreciation in property value. By and large, the coefficients of the hedonic regression have the expected signs and magnitudes. The coefficients on the housing characteristic variables all have the anticipated sign: the variables that were included concerned bedrooms, bathrooms, total rooms, and square feet of the house. The conclusion is robust in that it continues to hold after controlling for unmeasured, underlying factors that vary, such as unique market conditions.

There is a well-established link between property values and changing environmental amenities generally, and to lake levels in particular. Together, the theory and empirical evidence support the hypothesis that changing lake water levels influenced shoreline values on Lake Koshkonong. In this study, the repairs to the Indianford Dam, the corresponding decline in water levels at Lake Koshkonong, and the public's knowledge of these issues caused a substantial change in demand that contributed to a significant decrease in shoreline property values and local tax revenues.

\section{ACKNOWLEDGEMENTS}

The authors would like to thank Raquel Huppert and Christian Huppert for valuable help in the collection of the data. The author's would also like to thank the Rock Koshkonong Lake District for support of the project and data collection efforts. 


\section{AUTHOR BIOGRAPHIES}

Russell Kashian is Professor of Economics at the University of Wisconsin Whitewater, serves as a Specialist for the University of Wisconsin Extension and is co-founder and Director of the Fiscal and Economic Research Center at the University of Wisconsin Whitewater. Dr. Kashian's major fields of research include regional planning and regional financial institutions; he has published in a wide variety of journals and has extensive experience studying community financial institutions with research in subchapter $\mathrm{S}$ banking, credit unions, and minority banking. Dovetailing with his interest in local communities, Dr. Kashian's research also focuses on the regional distribution and economic impact of the Wisconsin Real Estate Market.

Matthew Winden is Assistant Professor of Economics at the University of Wisconsin Whitewater. Dr. Winden's major fields of research include environmental and natural resource valuation and policy; he has experience employing conjoint choice analysis to the study of biofuels, water credit markets and freshwater beaches.

Alexander Walker is a graduate of University of Wisconsin Whitewater, obtaining his B.S. in Economics in May 2015.

\section{REFERENCES}

Boyle, K.J. and L.O. Taylor. 2001. "Does the Measurement of Property and Structural Characteristics Affect Estimated Implicit Prices for Environmental Amenities in a Hedonic Model?" Journal of Real Estate Finance and Economics, 22 (2) 303 318.

Brown, G., and H. Pollakowski. 1977. "Economic Value of Shoreline.” The Review of Economics and Statistics, 59 (3) $231-249$.

Colwell, P.F., and C.A. Dehring. 2005. "The pricing of lake lots." The Journal of Real Estate Finance and Economics, 30(3) 267-283.

Conner, J. R., K.C. Gibbs, and J.E. Reynolds. 1973. “The Effects of water frontage on recreational property values.” Journal of Leisure Research, 5 (2) 26-38.

David, E.L. 1968. “Lakeshore Property Values: A Guide to Public Investment in Recreation.” Water Resources Research 4 (4) 697-707.

Epp D., and K.S. Al-Ani. 1979. “The Effect of Water Quality on Rural Non-Farm Residential Property Values.” American Journal of Agricultural Economics, 61 (3) 529-534.

Gibbs, J.P., J.M. Halstead, K.J. Boyle, and J.C. Huang. 2002. "An hedonic analysis of the effects of lake water clarity on New Hampshire lakefront properties." Agricultural and Resource Economics Review, 31(1), 39-46.

Hanson, L.U. and T.R. Hatch. 2001. "Change and Conflict in Land and Water Use: Resource Valuation in conflict Resolution Among Competing Users." Journal of Agricultural and Applied Economics, 33 (2) 297-306.

Khatari-Chhetri, J. B. and J. C. Hite. 1989. "Impact of an Interbasin Water Transfer on the Market Values of Lakeshore Properties." Working Paper, Strom Thurmond Institute, Clemson University.

Krysel, C., E.M. Boyer, C. Parson and P. Welle. 2003. "Lakeshore property values and water quality: Evidence from property sales in the Mississippi Headwaters Region." Walker, MN: Mississippi Headwaters Board.

Lansford, N.H., and L.L. Jones. 1995a. "Recreational and aesthetic value of water using hedonic price analysis." Journal of Agricultural and Resource Economics, 341-355.

Lansford, N.H. and L.L. Jones. 1995b. "Marginal Price of Lake Recreation and Aesthesis: An Hedonic Approach". Journal of Agricultural and Allied Economics, 27 (1) 212-223.

Michael, H.J., K.J. Boyle, \& R. Bouchard. 1996. "MR398: Water Quality Affects Property Prices: A Case Study of Selected Maine Lakes.” Digitalcommons.library.umaine.edu, accessed 3/25/2015

Michael, H.J., K.J. Boyle, and R. Bouchard. 2000. "Does the Measurement of Environmental Quality Affect Implicit Prices Estimated from Hedonic Models?" Land Economics, 76 (2) 283-298.

Michael, J.A., D.A. Sides and T.E. Sullivan. 2003. "The Economic Cost of Sea Level Rise to Three Chesapeake Bay Communities." The Maryland Coastal Zone Management Program.

Murray, M.N. 2003. "Economic Effects of TVA Lake Management Policy in East Tennessee.” Center for Business and Economic Research. University of Tennessee. http://cber.utk.edu/lakeres/HUD0.pdf accessed 3/25/2105

Palmquist, R.B. 1984. "Estimating the Demand for the Characteristics of Housing". The Review of Economics and Statistics, 66 (3) 394-404.

Parsons, G.R. and Y. Wu. 1991. "The Opportunity Cost of Coastal and Use Controls: An Empirical Analysis.” Land Economics, 67 (3) 308-316.

Payne, J.W. 1982. "Contingent Decision Behavior”. Psychological Bulletin, 92 (2) 382-402.

Poor, P.J., K.J. Boyle, L.O. Taylor, and R. Bouchard. 2001. "Objective versus Subjective Measures of Water Clarity in Hedonic Property Value Models”. Land Economics, 77 (4). 482-493.

Puto, C.P. 1987. “The Framing of Buying Decisions." Journal of Consumer Research, 14 (3). 301-315. 
Rosen, S. 1974. "Hedonic Prices and Implicit Markets: Product Differentiation in Pure Competition.” Journal of Political Economy, 82 (1). 34-55.

Singh, H. 1988. "Investigating the Compatibility of Econometric Forecasts and Subjective Expectation: A Suggested Framework." Journal of Economic Psychology, 9 (2). 233-249.

White, H. 1980. "A Heteroscedasticity-Consistent Covariance Matrix Estimator and a Direct Test for Heteroscedasticity." Econometrica, 48 (4). 817-838.

Williams V. 1994. "Selected Aspects of Lake Economics.” Georgia Lake Management Society Meeting. 1-6

Yates, T. 2009. "Operation assessment of reservoirs in the Savannah River Basin." All Theses. Paper 639.

Young, C. E., and F. A. Teti. 1984. "The Influence of Water Quality on the Value of Recreational Properties Adjacent to St Albans Bay.” US Department of Agriculture: Economics Research Service. Natural Resource Economics Division. 
Table 1. Lake Characteristics

\begin{tabular}{lcccc}
\hline Lake Characteristic & Koshkonong & Beaver Dam & Sinissippi & Big Muskego \\
\hline Total Lake Houses & 413 & 401 & 428 & 117 \\
Houses Sold (1997-2013) & 47 & 131 & 91 & 39 \\
County Location & Jefferson, Dane, Rock & Dodge & Dodge & Waukesha \\
Distance to Chicago & 129 miles & 155 miles & 145 miles & 87 miles \\
Distance to Milwaukee & 62 miles & 67 miles & 57 miles & 20 miles \\
Distance to Madison & 33 miles & 40 miles & 50 miles & 83 miles \\
Size Covered & 10,460 acres & 6,542 acres & 2,800 acres & 2,260 acres \\
Maximum Depth & 7 feet & 7 feet & 8 feet & 8 feet \\
Total Lake Frontage & 31,938 feet & 46,719 feet & 40,615 feet & 12,953 feet \\
\hline
\end{tabular}

Table 2. Descriptive Statistics

\begin{tabular}{|c|c|c|c|}
\hline Variable & Observations & Mean & Std. Dev. \\
\hline Sold price & 293 & $\$ 223,378.20$ & $\$ 169,657.10$ \\
\hline Epoch1 X Frontage X Beaver Dam & 293 & 9.661 & 33.448 \\
\hline Epoch1 X Frontage X Sinissippi & 293 & 5.990 & 29.655 \\
\hline Epoch1 X Frontage X Muskego & 293 & 6.039 & 34.467 \\
\hline Epoch2 X Frontage X Koshkonong & 293 & 2.110 & 16.161 \\
\hline Epoch2 X Frontage X Beaver Dam & 293 & 16.380 & 52.709 \\
\hline Epoch2 X Frontage X Sinissippi & 293 & 8.393 & 26.582 \\
\hline Epoch2 X Frontage X Muskego & 293 & 8.630 & 46.387 \\
\hline Epoch3 X Frontage X Koshkonong & 293 & 6.594 & 24.436 \\
\hline Epoch3 X Frontage X Beaver Dam & 293 & 22.679 & 75.432 \\
\hline Epoch3 X Frontage X Sinissippi & 293 & 12.867 & 37.997 \\
\hline Epoch3 X Frontage X Muskego & 293 & 4.481 & 33.473 \\
\hline Epoch1 X Beaver Dam & 293 & 0.101 & 0.301 \\
\hline Epoch1 X Sinissippi & 293 & 0.055 & 0.229 \\
\hline Epoch1 X Muskego & 293 & 0.045 & 0.209 \\
\hline Epoch2 X Koshkonong & 293 & 0.023 & 0.149 \\
\hline Epoch2 X Beaver Dam & 293 & 0.159 & 0.366 \\
\hline Epoch2 X Sinissippi & 293 & 0.107 & 0.310 \\
\hline Epoch2 X Muskego & 293 & 0.055 & 0.229 \\
\hline Epoch3 X Koshkonong & 293 & 0.091 & 0.288 \\
\hline Epoch3 X Beaver Dam & 293 & 0.166 & 0.372 \\
\hline Epoch3 X Sinissippi & 293 & 0.133 & 0.340 \\
\hline Epoch3 X Muskego & 293 & 0.029 & 0.169 \\
\hline Ln (Lot Size/Frontage) & 293 & 5.373 & 0.899 \\
\hline Square Feet of House & 293 & 1935.218 & 1228.468 \\
\hline Total Rooms & 292 & 6.837 & 2.093 \\
\hline Half-Baths & 293 & .273 & 0.467 \\
\hline Full Bathrooms & 293 & 1.718 & 0.804 \\
\hline Near Distance Ft & 293 & 333.505 & 300.415 \\
\hline Near_Distance FtSqrd & 293 & 201166.3 & 551217.3 \\
\hline
\end{tabular}


Table 3. Hedonic Regression Results

\begin{tabular}{|c|c|c|c|}
\hline Sold price (Dependent Variable) & Coefficient & Std. Err. & P-value \\
\hline Epoch1 X Frontage X Beaver Dam & 263.5809 & 404.3224 & 0.515 \\
\hline Epoch1 X Frontage X Sinissippi & 256.0717 & 161.6678 & 0.114 \\
\hline Epoch1 X Frontage X Muskego & $-1034.197 * * *$ & 379.0997 & 0.007 \\
\hline Epoch2 X Frontage X Koshkonong & $675.7016^{* *}$ & 298.8583 & 0.025 \\
\hline Epoch2 X Frontage X Beaver Dam & 227.8256 & 226.233 & 0.315 \\
\hline Epoch2 X Frontage X Sinissippi & 324.2352 & 283.837 & 0.254 \\
\hline Epoch2 X Frontage X Muskego & 329.1649 & 285.3094 & 0.250 \\
\hline Epoch3 X Frontage X Koshkonong & $698.2997 * *$ & 294.7833 & 0.019 \\
\hline Epoch3 X Frontage X Beaver Dam & 139.3263 & 139.3356 & 0.318 \\
\hline Epoch3 X Frontage X Sinissippi & $782.1963 * * *$ & 89.41922 & 0.000 \\
\hline Epoch3 X Frontage X Muskego & $3259.454 * *$ & 1365.512 & 0.018 \\
\hline Epoch1 X Beaver Dam & -31012.89 & 36013.14 & 0.390 \\
\hline Epoch1 X Sinissippi & 2134.115 & 20421.28 & 0.917 \\
\hline Epoch1 X Muskego & $105610.2 * *$ & 45831.03 & 0.022 \\
\hline Epoch2 X Koshkonong & 22540.9 & 38540.57 & 0.559 \\
\hline Epoch2 X Beaver Dam & $44963.64 *$ & 25227.2 & 0.076 \\
\hline Epoch2 X Sinissippi & $50928.55 * *$ & 25783.54 & 0.049 \\
\hline Epoch2 X Muskego & 70962.56 & 57962.38 & 0.222 \\
\hline Epoch3 X Koshkonong & 6781.707 & 29167.67 & 0.816 \\
\hline Epoch3 X Beaver Dam & 27318.99 & 21087.69 & 0.196 \\
\hline Epoch3 X Sinissippi & 25818.81 & 16099.85 & 0.110 \\
\hline Epoch3 X Muskego & $-220559.5^{*}$ & 133908.4 & 0.100 \\
\hline Ln (Lot Size/Frontage) & 1119.466 & 5755.195 & 0.846 \\
\hline Square Feet of House & 10.48218 & 7.110946 & 0.142 \\
\hline Total Rooms & $7522.521 * *$ & 3273.375 & 0.022 \\
\hline Half-Baths & $30923.36^{* *}$ & 13098.38 & 0.019 \\
\hline Bathrooms & $33229.11 * * *$ & 9594.035 & 0.001 \\
\hline Near_Dist_Ft & 10.06888 & 56.4265 & 0.859 \\
\hline Near_Dist_FtSqrd & -.0036785 & .0263418 & 0.889 \\
\hline Constant & 1266.691 & 34092.85 & 0.970 \\
\hline
\end{tabular}

Table 4. Costs to the Lakes

\begin{tabular}{|c|c|c|}
\hline Lake & Average Increase in Value & Relative Tax Loss \\
\hline Koshkonong & $\$ 54,000.12$ & \\
\hline Sinissippi & $\$ 74,226.41$ & $\$ 116,948.40$ \\
\hline Muskego & $\$ 149,177.83$ & $\$ 550,317.54$ \\
\hline
\end{tabular}

